University of Nebraska - Lincoln

DigitalCommons@University of Nebraska - Lincoln

1993

\title{
Atrazine in a Stream-Aquifer System: Transport of Atrazine and Its Environmental Impact Near Ashland, Nebraska
}

\author{
Darryl A. Blum \\ University of Nebraska - Lincoln \\ James D. Carr \\ University of Nebraska - Lincoln, jcarr1@unl.edu \\ Ralph K. Davis \\ University of Nebraska - Lincoln \\ Darryll T. Pederson \\ University of Nebraska - Lincoln, dpederson2@unl.edu
}

Follow this and additional works at: https://digitalcommons.unl.edu/watercenterpubs

Part of the Water Resource Management Commons

Blum, Darryl A.; Carr, James D.; Davis, Ralph K.; and Pederson, Darryll T., "Atrazine in a Stream-Aquifer System: Transport of Atrazine and Its Environmental Impact Near Ashland, Nebraska" (1993). Faculty Publications from The Water Center. 21.

https://digitalcommons.unl.edu/watercenterpubs/21

This Article is brought to you for free and open access by the Water Center, The at DigitalCommons@University of Nebraska - Lincoln. It has been accepted for inclusion in Faculty Publications from The Water Center by an authorized administrator of DigitalCommons@University of Nebraska - Lincoln. 


\title{
Atrazine in a Stream-Aquifer System: Transport of Atrazine and Its Environmental Impact Near Ashland, Nebraska
}

\author{
Darryl A. Blum \\ James D. Carr \\ Ralph K. Davis \\ Darryll T. Pederson
}

\begin{abstract}
The municipal wellfield for Lincoln, Nebraska, consists of 44 wells located adjacent to the Platte River near Ashland, Nebraska. The herbicide atrazine was monitored in the river and two transects of monitoring wells. The amount of atrazine transported down the Platte River in 1989, 1990, and 1991 was shown to increase each year. Induced recharge from the Platte River results in movement of atrazine from the river into the aquifer. A 2 I-day lag time was determined for the movement of atrazine from the river to a transect of monitoring wells 10 feet west of the bank. The role that colloids play on the transport of atrazine was determined to be insignificant. $A$ small percentage of atrazine found in the river was determined to come from rain water. The infiltration of agrichemical-contaminated river water was shown to significantly reduce the quality of raw water and finished water being produced by the adjacent aquifer.
\end{abstract}

\section{Introduction}

This study was designed to use the agricultural chemical atrazine as a means to trace the path of water moving along a zone of induced recharge within a river-aquifer system and to study the impact of agrichemicals on the surrounding environment. Atrazine (2-chloro-4- isopropylamino6-e thylamino-striazine CAS\# 1912-24-9) is a widely used triazine herbicide in the Platte Valley region and has been found to be transported into the Platte River with precipitation runoff (Snow and Spalding 1988; Duncan et al. 1991). It degrades in soil and water. The half-life has been estimated in soil to be between four and 57 weeks, depending on the temperature and soil type. The half-life in ground water has been approximated to be between 10 weeks and two years (Cohen et al. 1984; Dao et al. 1979). Therefore, atrazine can be used as a tracer of ground water movement because the half-life would extend beyond the time period of the study. Atrazine is typically applied by soil incorporation of a powder associated with clay particles, so very little would be sprayed directly into the air. Atrazine's solubility in water is $70 \mathrm{ppm}$ at $25^{\circ} \mathrm{C}$.

The system chosen was within the Lincoln municipal wellfield near Ashland, Nebraska. The wellfield consists of 44 wells in an alluvial aquifer adjacent to the Platte River. The Platte River acts as a line source of induced recharge, thus allowing contaminants already contained in the river to be used as a tracer of induced recharge (Duncan et al. 1991). As atrazine moved into the wellfield, concentrations were monitored in two transects of monitoring wells. These tran- 
sects were located between the riverbank and a production well, roughly perpendicular to the path of the river. For the remainder of this paper, "the river" will refer to the Platte River and the "north wellfield" and "south wellfield" will be representative of the Lincoln municipal wellfield.

The environmental aspect of this research concerns raw drinking water quality and air quality. It is shown that at certain times of the year the potential for contaminants to flow into the aquifer beneath the wellfield may be greater than at other times. It is known that contaminant concentrations in the Platte River can be episodic (Duncan et al. 1991; Snow and Spalding 1988; Shepherd 1991). It has also been shown that atrazine can enter the atmosphere and be deposited via precipitation (Buser 1990).

The typical method of determining ground water movement and velocity is the use of a tracer (Freeze and Cherry 1979; Davis et al. 1980). Contaminants already contained in subsurface water have been used as indicators of ground water velocity and dispersion. Due to agricultural application, atrazine is present in the river in detectable amounts. Its sorption and degradation under the conditions present in our study are considered to be insignificant (Cohen et al. 1984).

Previous studies using temperature and atrazine observations provided some understanding of the river-aquifer interaction (Duncan et al. 1991; Chu 1988; Shepherd 1991). Pumping tests were conducted in 1952 to determine the rate of recovery of the water table in relation to the level of the river stage (Black and Veatch 1964). Layne-Western (1974) tried to define the role of the aquifer to supply future demands as well as the function that the Platte River plays in recharging the adjacent aquifer.

\section{Location of Study Area}

The study area is located in the Lincoln municipal wellfield, which is three miles northeast of Ashland, Nebraska (Figure 1). Ashland is situated in the southeast corner of Saunders County approximately 35 miles northeast of Lincoln. The wellfield, situated on the west bank of the Platte River, is divided into the north and south wellfields by U.S. Highway 6. Transects of monitoring wells are located in both the north and south wellfields. An island is located in the middle of the river in the south wellfield. Early in the year, the flowing channel of the river reaches from the west bank to the east bank. Later in the year, about mid-summer, a dry riverbed extends outward from the west bank of the river. The Platte River in this region has a wide range of discharge levels dependent upon precipitation and season.

The wellfield is the principal source of water for the city of Lincoln, providing 97 percent of the water used in the metropolitan area (Obrist 1983). Lincoln is dependent upon the flow of water in the Platte River to recharge the aquifer during high demand periods (Black and Veatch 1964). The 44 production wells in the wellfield extract water from the alluvial aquifer, each pumping 1200 to 3000 gallons per minute. This pumping creates a localized depression in the water table and results in river water moving into the aquifer via induced recharge.

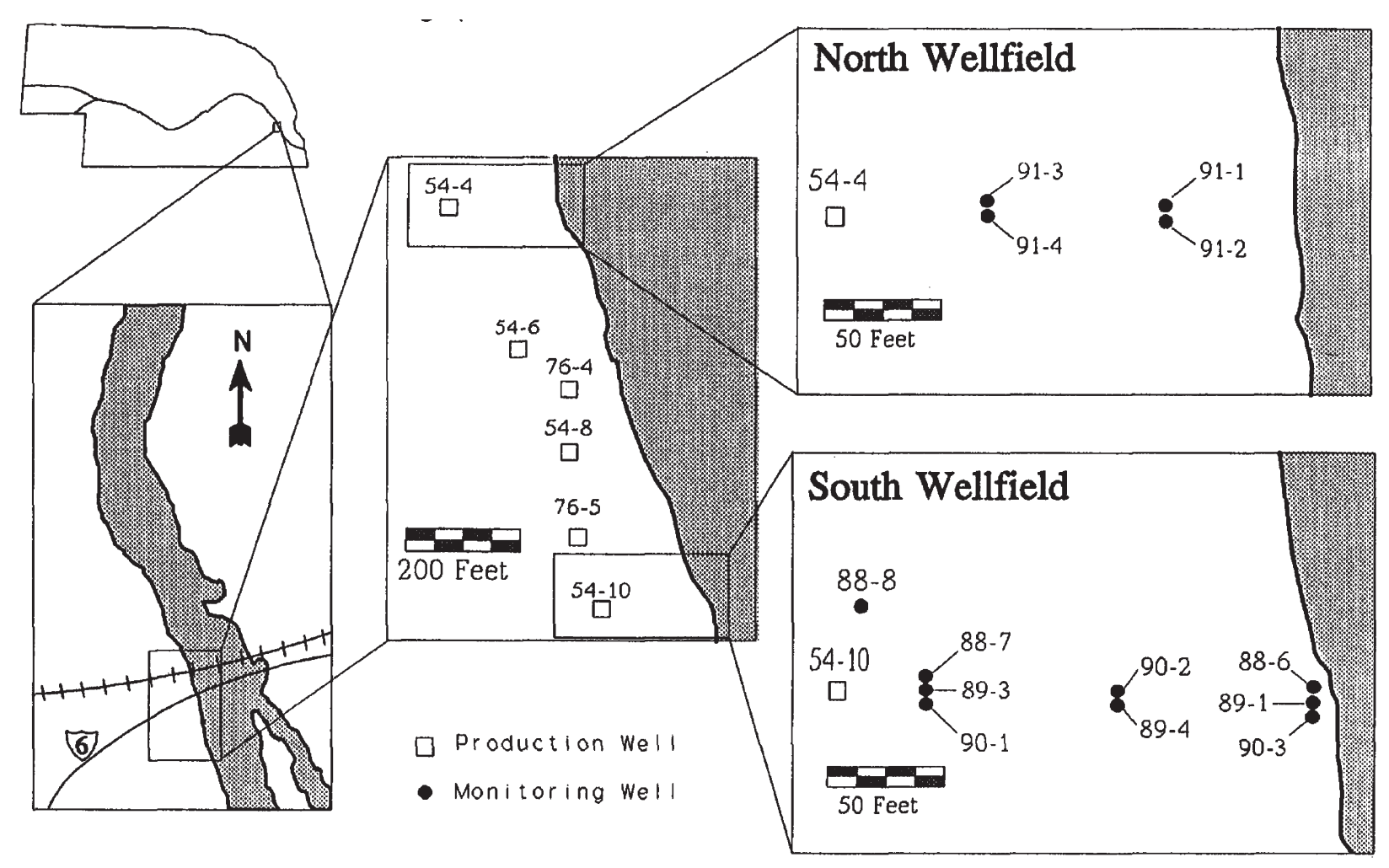

Figure I. Location of the study site near Ashland, Nebraska, depicting the wells sampled in this study. 


\section{Hydrogeology of the Study Area}

The alluvial aquifer in the study area is composed of sands and gravels ranging in thickness from 52 to 98 feet (16 to $30 \mathrm{~m}$ ) (Souders 1967). The aquifer is in direct hydraulic connection with the river in the wellfield (Chu 1988; Borgden 1972; Marlette 1952). The static water table outside the wellfield is relatively shallow ranging from 5 to 15 feet $(1.5$ to $4.6 \mathrm{~m})$ below the surface. The gradient of the static water table is less than 5 feet per mile and slopes toward the Platte River (Souders 1967; GMI 1987).

\section{Model of Atrazine Movement}

Atrazine is a herbicide used widely in the Platte River Basin of Nebraska to control broad leaf and some grass weeds and can be used as a non-selective herbicide at higher rates of application. Atrazine is applied during the planting season in spring and early summer and can be found near the surface of the soil at this time (Cohen et al. 1984). Precipitation runoff causes atrazine to enter the surface water system. Water which leaves the river through induced recharge carries the atrazine with it. All of the atrazine found in the wells is judged to come from induced recharge because atrazine is not applied in the immediate study area, which is grassland and wooded areas. Also, the direction of ground water flow in the immediate surrounding area is from the river to the wellfield.

Two factors affect the amount of atrazine in the river: (1) the timing of the precipitation event in relation to the time of application, and (2) the amount of precipitation received. After application, atrazine will be at the surface of the soil. It is at this time that atrazine is most mobile. Atrazine is transported with precipitation runoff to the surface water system. As the discharge increases, a maximum atrazine concentration is attained followed by a decrease due to dilution. Thus, the atrazine concentration in the river depends both on the amount of atrazine available for transport and the volume of water.

The Platte River discharge is significantly affected by runoff during precipitation events in the contributing basin of 84,200 square miles (USGS 1991). During the study, a maximum flow of the river at Ashland of 40,000 cubic feet per second was recorded on June 6, 1991. During drier periods, the discharge drops substantially. A minimum flow of 610 cubic feet per second was recorded on September 4, 1991 (USGS 1991).

\section{Methods}

The study utilized the Platte River, two production wells, 13 monitoring wells, and two sets of well bundles in groups of two and four (Figure 1). Monitoring wells in the south wellfield are 10, 80, and 160 feet $(3,24.6$, and $49.2 \mathrm{~m})$ from the riverbank, and are screened at depths of 15, 26, and 58 feet, respectively $(4.6,8.0$, and $17.8 \mathrm{~m})$. Well nests in the north wellfield are 60 and 135 feet (18.5 and $41.5 \mathrm{~m})$ from the riverbank and screened at depths of 25 and 45 feet (5.8 and $12.0 \mathrm{~m}$ ). Well bundle 1 is located directly below the riverbed 12 feet $(3.7 \mathrm{~m})$ from the bank in the south well- field near production well 54-10 and screened at 1.2, 2.1, 3.0 , and 4.9 feet $(0.36,0.65,1.0$, and $1.5 \mathrm{~m})$. Well bundle 3 is located under the riverbed 12 feet $(3.7 \mathrm{~m})$ offshore from the west bank of the island. These well bundles had been installed at a time when the river was naturally dry (bundle 1 ), and dewatered for installation of a pipeline (bundle 3). Production wells 54-10 and 54-4 are each located about 200 feet $(61.5 \mathrm{~m})$ from the river. The water at the river's edge, where the river sample was taken, is assumed to be the water recharging the aquifer, but the possibility of error in this assumption is recognized.

Samples were gathered in cleaned 500-mL amber glass reagent bottles as described by Duncan et al. (1991). Tap water samples were collected from a faucet after water had run continuously for at least 25 minutes to ensure the water being collected was from the water main. The sample bottle was rinsed with the sample water three times prior to retention of the sample. Samples were taken to the laboratory and allowed to sit undisturbed and refrigerated to allow silt to settle to the bottom.

The analytical method used was developed by Shepherd to determine the concentration of aqueous atrazine easily and quickly at sub-part-per-billion levels (Shepherd et al. 1992). The sample was filtered with 0.45 -pm filter paper (except for the colloid study described later) to remove any silt. A $10-\mathrm{mL}$ portion of $10 \mathrm{ppb}$ terbuthylazine was added as an internal standard to a $100-\mathrm{mL}$ volumetric flask, and then diluted to the mark with sample. A 10-mL portion of this solution was extracted via a Supelco C-18 solid-phase extraction cartridge and dried with dry nitrogen. The analytes and internal standard were eluded from the resin into a reduction vessel with two $250-\mu \mathrm{L}$ aliquots of ethyl acetate. The contents of the reduction vessel were blown to dryness with nitrogen, then redissolved with $50 \mu$ of ethyl acetate. This was then blown down to about 5 to $7 \mu \mathrm{L}$ and the entire volume was injected into a Hewlett Packard 5890 gas chromatograph coupled to a Hewlett Packard 5970 mass spectrometer. The data were gathered by single ion monitoring. The mass to charge ions monitored were 173, 200, 215, and 229. From the total ion chromatogram, the atrazine and terbuthylazine peak areas were integrated. The ratio of the area of the atrazine peak divided by the area of the terbuthylazine peak was compared to a standard curve. A slight deviation from this method was employed when sample concentrations greater than $4 \mathrm{ppb}$ were expected. In such cases, the sample was diluted by pipetting an appropriate aliquot of the filtered sample to a 10-mL volumetric flask and adding the terbuthylazine spike. The volumetric flask was diluted to the mark with atrazine-free double-distilled water. This modification to the method was needed due to the high concentrations of atrazine measured in mid-May through August. Precision, accuracy, and recovery of the method are described by Shepherd et al. (1992).

\section{Results}

Data collected from all of the monitoring wells are presented in Table 1. Concentrations are presented in parts per 
Table I. Atrazine Concentration (ppb) for 1991

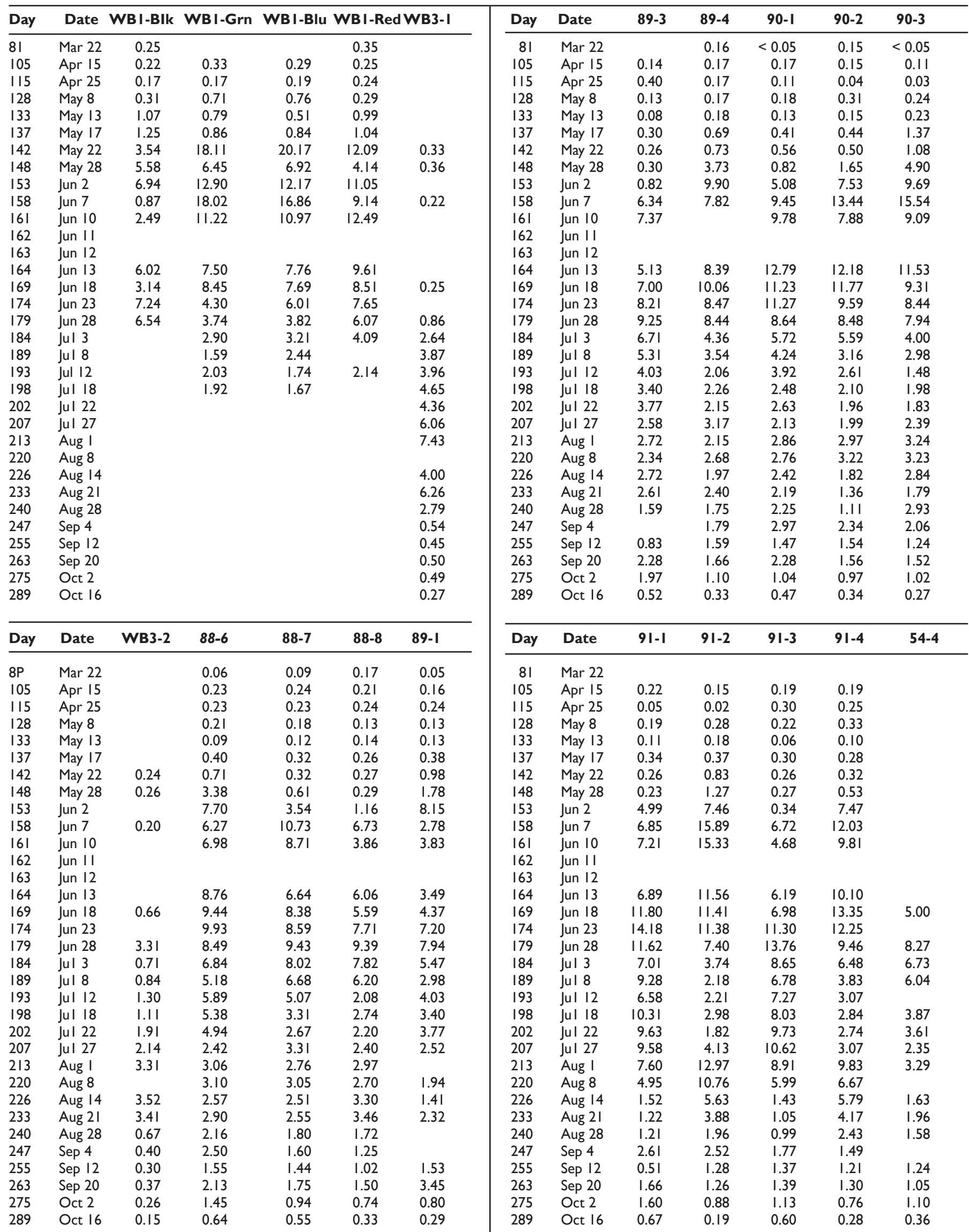




\begin{tabular}{|c|c|c|c|c|}
\hline Day & Date & 54- 10 & River & Tap \\
\hline 81 & Mar 22 & & 0.07 & 0.48 \\
\hline 105 & Apr I5 & & 0.41 & 0.52 \\
\hline 115 & Apr 25 & & 0.04 & 0.52 \\
\hline 128 & May 8 & & 1.19 & \\
\hline 133 & May 13 & & 1.79 & 0.51 \\
\hline | 37 & May 17 & & 6.39 & 0.73 \\
\hline 142 & May 22 & & 9.00 & 0.94 \\
\hline |48 & May 28 & 0.29 & 10.57 & 0.49 \\
\hline 153 & Jun 2 & 1.93 & 18.95 & 0.79 \\
\hline 158 & Jun 7 & 3.92 & 15.77 & 1.30 \\
\hline 161 & Jun 10 & 3.67 & 11.86 & 0.97 \\
\hline 162 & Jun II & & 6.33 & \\
\hline 163 & Jun 12 & & 4.27 & \\
\hline 164 & Jun 13 & 4.37 & 4.46 & 0.90 \\
\hline 169 & Jun 18 & 5.19 & 5.13 & 0.97 \\
\hline 174 & Jun 23 & & 5.28 & 2.09 \\
\hline 179 & Jun 28 & 7.18 & 2.33 & 1.23 \\
\hline 184 & Jul 3 & 6.49 & 2.07 & 1.43 \\
\hline 189 & Jul 8 & 5.52 & 1.84 & 1.49 \\
\hline 193 & Jul I2 & & 1.51 & 1.29 \\
\hline 198 & Jul 18 & 5.07 & 3.24 & \\
\hline 202 & Jul 22 & 4.35 & 1.78 & 1.57 \\
\hline 207 & Jul 27 & 2.69 & 1.34 & 1.40 \\
\hline 213 & Aug I & 3.95 & 1.45 & 1.44 \\
\hline 220 & Aug 8 & 2.92 & 0.91 & 1.13 \\
\hline 226 & Aug 14 & 3.21 & 0.79 & 1.00 \\
\hline 233 & Aug 21 & 2.88 & 0.69 & 1.64 \\
\hline 240 & Aug 28 & 2.03 & 0.54 & 1.21 \\
\hline 247 & Sep 4 & 1.85 & 0.42 & \\
\hline 255 & Sep 12 & & 0.36 & 1.51 \\
\hline 263 & Sep 20 & & 0.64 & \\
\hline 275 & Oct 2 & & 0.40 & 1.70 \\
\hline 289 & Oct 16 & & 0.16 & 0.68 \\
\hline
\end{tabular}

Figure 3. Atrazine concentrations throughout 1991 in the Platte River, monitoring well 88-6, and production well 5410. Peaks identified as I, II, and III in the river have given rise to peaks identified as A, B, and C, respectively, in well 88-6.

billion (ng/mL). Atrazine levels measured in the river were significantly higher in 1991 than in 1989 and 1990. Figure 2 shows the concentration of atrazine in the river in 1989, 1990, and 1991. Most of the atrazine detected in 1991 was transported down the river in late spring and early summer in one large band. This is probably due to the frequent rains received in the Platte Valley drainage basin very early in the growing season of 1991 . Heavy rains ranging from 0.3 to 4.0 inches were reported on May 17, June 2, 5, 13, and 14 at three upstream recorder stations. This rainfall pattern was fairly similar to 1990 but very different from 1989 when a much smaller amount of rain fell early in the summer (Duncan et al. 1991).

The total amount of atrazine contained in the river water in 1989, 1990, and 1991 can be calculated from past studies and these data. River flow data were obtained from

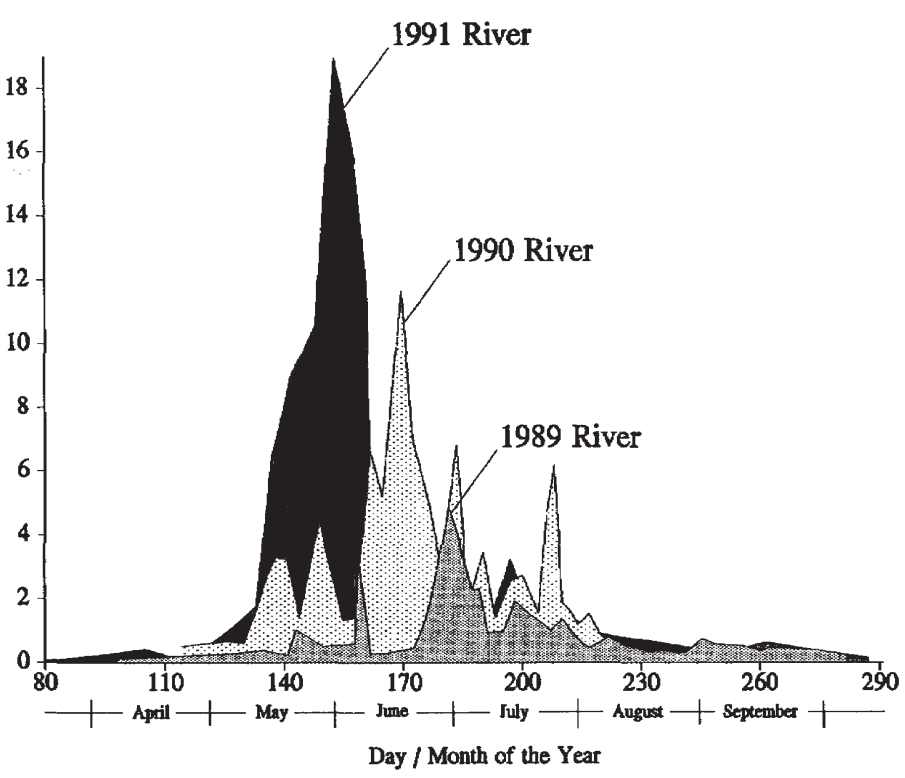

Figure 2. Atrazine concentration in the Platte River in 1989, 1990, and 1991.

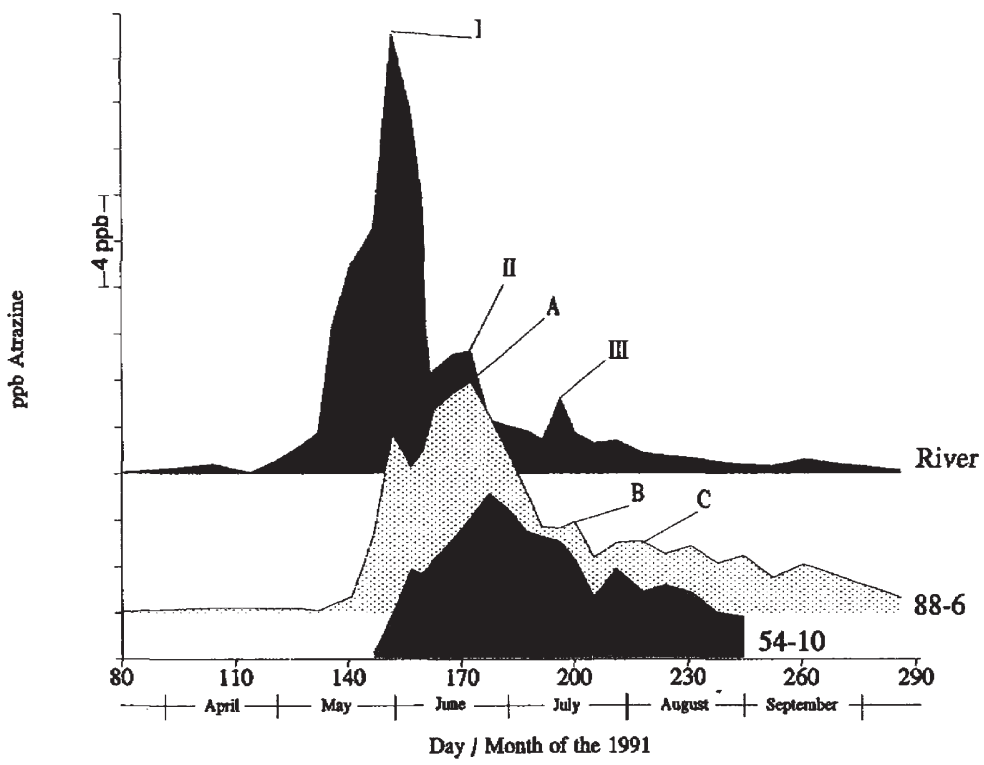

the Nebraska district of the U.S. Geological Survey for all three years. An estimate of the concentration of atrazine in the river for each day can be obtained by interpolation of the data. By multiplying the estimated atrazine concentration by the volume flowing past the sampling station each day, the total mass of atrazine discharging that day can be calculated. Summing the amount of atrazine for each day between March and October gives a good estimate of the amount of atrazine transported in the river water in 1989, 1990, and 1991. In 1989, a total of 3,092 pounds $(1,403 \mathrm{~kg})$ of atrazine was washed down the river between March and October. In 1990, 22,386 pounds $(10,157 \mathrm{~kg})$ were carried in the river, while in $1991,33,186$ pounds $(15,057 \mathrm{~kg})$ were transported in the river between March and October. We attribute these changes to the amount of rain and time of the year the rain was received, because no widespread changes 
in agricultural practices occurred during these years. It is most probable that a larger amount of atrazine is at or near the soil surface (and therefore easily transported by water) early in the planting season shortly after application.

In 1987, 11 million $\mathrm{kg}$ (12,000 tons) of atrazine were applied throughout Nebraska (Shepherd 1991). The amount of atrazine applied in 1989, 1990, and 1991 should be relatively consistent with that in 1987. Since the Platte River drains about half of the entire area in which atrazine is applied in Nebraska, it may be estimated that less than 0.15 percent of the total atrazine applied in Nebraska was contained in the river water as the intact molecule in 1991.

\section{Lag Time for Infiltration into the Aquifer}

The movement of atrazine from the river into the wellfield is depicted in Figure 3. Peaks of concentration in the river and in well 88-6 are labeled to show the time lag. Peak A has a 21-day lag time from peak I, while peak B has a 22-day lag time from peak II. Peak $C$ and peak III also differ by 21 days. This corresponds to approximately a 21-day delay for infiltration of surface water to ground water at well 88-6. This is significantly different than the 10-day delay previously reported (Duncan et al. 1991). In the interpretation of the 1989 data, it was suggested that early, short time peaks in the river did not contribute atrazine to the monitoring wells. This is now known to be false. Also in 1989 , several small peaks were seen in the river, some of which did not correlate well with those in well 88-6. In general, observations of lower concentrations of atrazine and numerous concentration peaks in the river in 1989 yielded the incorrect 10-day delay estimate.

The peak of atrazine concentration in well 88-6 prior to peak A would correlate to a peak on the front shoulder of peak I in the river (Figure 3). Evidence of a missed peak of atrazine concentration is clearly shown by well bundle 1-Blue (Table 1). The atrazine concentration reached greater than $20 \mathrm{ppb}$ on day 142 , dropped to 6.45 , and then increased, showing two resolved peaks. The absence of this peak in the river can be attributed to the sampling frequency. During this time period, approximately five days passed between the gathering of samples, which is ample time for a band of atrazine to flow down the river and not be detected. The decrease in height and increase in width of the peaks in this figure reflect atrazine dispersion as it entered the wellfield.

\section{The Effect of Colloids on the Transport of Atrazine}

A series of experiments were carried out to determine the extent to which atrazine adsorbed on colloids is transported in the river and into the adjacent aquifer. The river sample collected on June 12, 1991, was diluted fourfold to bring the atrazine concentration in the range of the standard curve. The well sample, gathered on October 2, 1991, was a mixture from wells 88-6, 88-7, 88-8, and 89-1 to ensure a representative sample of the aquifer. The analyses of both the river and well samples were done on October 4,1991 . By comparing the river sample concentration of atrazine analyzed on June $12(4.27 \mathrm{ppb})$ to that on October $2(4.17 \mathrm{ppb})$, it can be seen that degradation of atrazine in
Table 2. Atrazine Concentrations (ppb) in Filtered River and Ground Water

\begin{tabular}{ccc}
\hline $\begin{array}{c}\text { Filter Pore } \\
\text { Size } \\
(\mu \mathrm{m})\end{array}$ & $\begin{array}{c}\text { Atrazine in } \\
\text { the River } \\
(\mathrm{ppb})\end{array}$ & $\begin{array}{c}\text { Atrazine in } \\
\text { the Wells } \\
(\mathrm{ppb})\end{array}$ \\
\hline 0.015 & 4.14 & 0.93 \\
0.030 & 4.21 & 0.84 \\
0.050 & 4.19 & 0.83 \\
0.080 & 4.18 & 0.83 \\
0.100 & 4.21 & 0.80 \\
0.200 & 4.19 & 0.82 \\
0.450 & 4.08 & 0.84 \\
\hline
\end{tabular}

Table 3. Atrazine Concentrations (ppb) in Rain Water

\begin{tabular}{rlr}
\hline Day & Date & [ATZ] \\
\hline 85 & Mar 26 & 0.18 \\
98 & Apr 8 & 0.10 \\
102 & Apr 12 & 0.27 \\
116 & Apr 26 & 0.25 \\
124 & May 4 & 0.74 \\
136 & May 16 & 1.83 \\
149 & May 29 & 1.14 \\
152 & Jun I & 0.84 \\
164 & Jun 13 & 0.94 \\
190 & Jul 5 & 1.27 \\
217 & Aug 5 & 0.22 \\
219 & Aug 7 & 0.50 \\
250 & Sep 7 & 0.10 \\
254 & Sep I & $<0.05$ \\
296 & Oct 24 & $<0.05$ \\
308 & Nov 4 & $<0.05$ \\
\hline
\end{tabular}

this time period was minimal. Membrane filtration techniques were used on both samples with filters ranging in pore size from 15 to 450 nanometers (nm). Long times, up to 10 hours, were necessary to filter the sample through the 15-nm pore size filter. The filtered samples were analyzed for atrazine (Table 2). Since no significant difference in atrazine concentration was observed from one pore size to the next, and colloid dimensions are generally considered to be between $10 \mathrm{~nm}$ and $1000 \mathrm{~nm}$, colloids play an insignificant role in the transport of atrazine in the river or from the river into the adjacent aquifer. Rather, atrazine is present in water as dissolved molecules.

\section{Atrazine in Precipitation}

Table 3 shows the concentration of atrazine measured in precipitation. Rain samples were taken on the roof of Hamilton Hall on the city campus of the University of Nebraska-Lincoln. Samples were collected in a clean 200$\mathrm{mL}$ test tube capped with a clean 8-inch funnel. A piece of clean parafilm with small pin holes in it to prevent evaporation was placed over the bottom tube of the funnel when time between precipitation events and sample gathering was long. The uncontrollable factors, such as the time be- 
tween precipitation events and the amount of precipitation received, may have had an effect on the concentration of atrazine measured. The concentration of atrazine in the precipitation increased in April and May and reached a maximum of $1.83 \mathrm{ppb}$ on day 136, May 16. This corresponds well to the time of agricultural application of atrazine. After application, the concentration of atrazine in precipitation declined, but remained at a significant level through August. Figure 4 presents the precipitation data in graphical form overlaying a representation of the concentration of atrazine in the river. A small percentage of the atrazine contained in the river originated from precipitation. Also, the most likely time for agrichemicals to be released as contaminants to the environment is during the application season.

There are two possible ways for atrazine to be released into the upper atmosphere, sublimation and adsorption onto dust particles being blown into the atmosphere. Atrazine has a vapor pressure of $3.0 \times 10^{-7}$ millibar at $20^{\circ} \mathrm{C}$. This would give a concentration of about $2.2 \mathrm{ppb}$ in atrazine-saturated air at 20 degrees. Previous reports of concentrations of atrazine in precipitation suggest that both modes of release are viable (Buser 1990).

\section{Impact on Water Quality}

In order to assess the environmental effect of induced recharge on raw water quality, a series of production wells were sampled three times in the summer and fall of 1991. Table 4 lists the production wells and gives the concentration of atrazine in parts per billion as well as the date the samples were gathered. Three of the production wells were turned off during the first two samplings, which led to the absence of three samples. On October 30, 14 of the 26 wells were already winterized, which left only 12 samples to be analyzed on this date. Figure 5 represents the wellfield with the production wells labeled in bold. Eleven production wells showed significant atrazine concentrations on July 12, day 193, 40 days after the maximum atrazine concentration was measured in the river. An additional six wells showed appreciable atrazine concentrations on September 10, day 253. This was 100 days after the maximum atrazine concentration was measured in the river. By October 30, day 303, dispersion and degradation of atrazine should have decreased the concentration found in ground water, but a significant increase in atrazine concentration was observed in production well 54-7.

The first tier of production wells close to the river show a high atrazine concentration on July 12, the first sampling date. The wells farther away from the river that are protected or screened by another production well do not have significantly increased levels of atrazine for this date. Approximately 40 percent of the production wells sampled were significantly affected by induced recharge from the river in 40 to 50 days.

Atrazine was found at a concentration greater than 2 ppb on June 23, 1991, in tap water (Table 1). The concentration remained between 1 and 2 ppb until late in October, after which time it declined. Contaminants in the river significantly degrade the raw water and drinking water quality

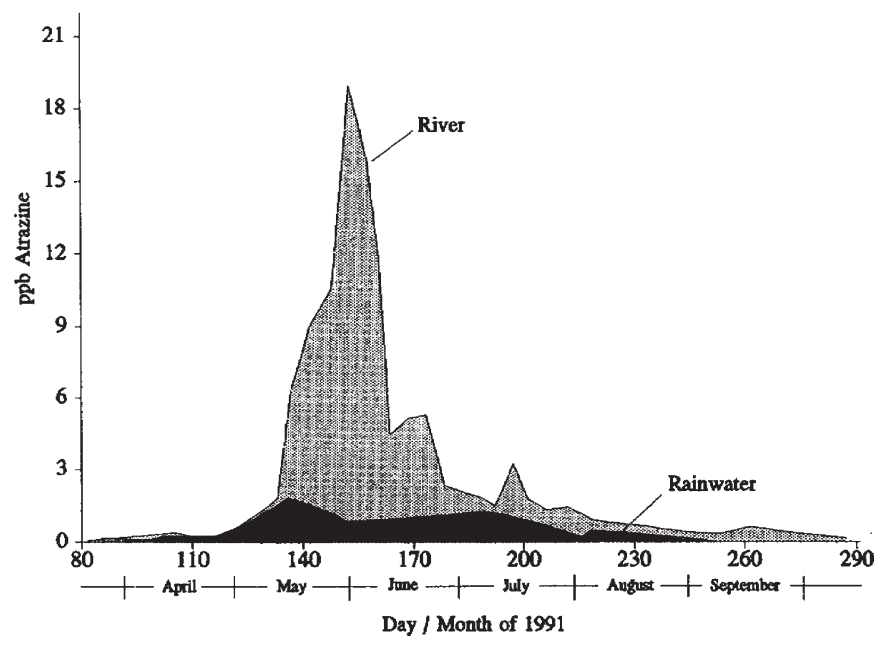

Figure 4. Atrazine concentration in rain water and in the Platte River.

Table 4. Atrazine Concentrations (ppb) in the Production Wells for 1991

\begin{tabular}{|c|c|c|c|c|}
\hline $\begin{array}{l}\text { Well } \\
\text { No. }\end{array}$ & $\begin{array}{c}\text { Distance to } \\
\text { Bank of River } \\
\text { (feet) }\end{array}$ & $7-|2-9|$ & $9-|0-9|$ & $|0-30-9|$ \\
\hline $49-6$ & 1800 & 0.33 & 0.45 & \\
\hline $54-1$ & 150 & 0.18 & 5.43 & 0.62 \\
\hline $54-3$ & 700 & 0.53 & 4.47 & 0.70 \\
\hline $54-4$ & 200 & 6.04 & 1.24 & 0.36 \\
\hline $54-5$ & 650 & 1.96 & 5.43 & 1.30 \\
\hline $54-7$ & 700 & 0.05 & 0.80 & 1.92 \\
\hline $54-10$ & 200 & 5.52 & 1.85 & \\
\hline 54-1I & 550 & 1.84 & 1.68 & 0.60 \\
\hline $56-1$ & 150 & 2.88 & 2.03 & 1.09 \\
\hline $56-5$ & 125 & 4.12 & 1.62 & 0.32 \\
\hline $56-7$ & 750 & 0.96 & 0.90 & \\
\hline $56-9$ & 1200 & 0.73 & 0.39 & 0.11 \\
\hline $57-1$ & 225 & 0.54 & 2.32 & \\
\hline $66-1$ & 2150 & 0.16 & 0.18 & \\
\hline $66-2$ & 2300 & $<0.05$ & & \\
\hline $66-3$ & 1675 & & 0.08 & \\
\hline $66-4$ & 1175 & 0.43 & 0.66 & \\
\hline $66-5$ & 1550 & $<0.05$ & 0.12 & \\
\hline $66-6$ & 1350 & 0.24 & 0.32 & \\
\hline $76-1$ & 850 & 0.27 & 3.13 & \\
\hline $76-2$ & 850 & 0.53 & 1.90 & \\
\hline $76-3$ & 600 & 1.47 & 1.57 & \\
\hline $76-4$ & 50 & 6.97 & 1.03 & 0.39 \\
\hline $76-5$ & 75 & 5.53 & 1.02 & \\
\hline $79-2$ & 225 & 0.36 & 1.96 & 0.89 \\
\hline $86-2$ & 350 & 4.76 & & 0.81 \\
\hline
\end{tabular}

produced from the adjacent aquifer. Tap water is a mixture of water pumped from many wells, mixed in a 40-mile pipeline, and stored before delivery. Wellfield management kept tap water atrazine concentrations as low as possible, but no atrazine removal treatment such as activated charcoal was used prior to distribution. 
Platte River near Ashland, NE

North and South Wellfields

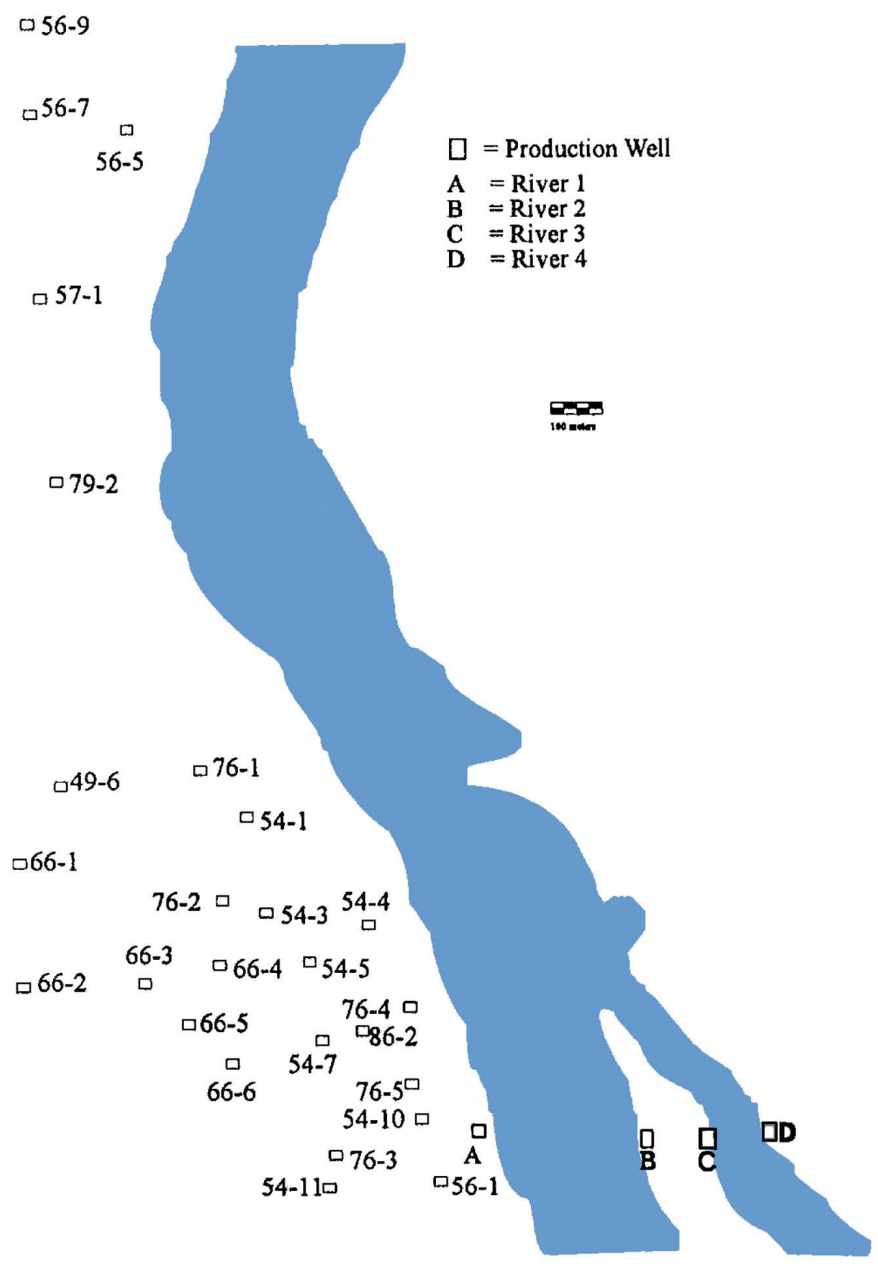

Figure 5. The locations of the 26 production wells sampled in the summer and fall of 1991. Refer to Table 4 for their atrazine concentrations.

\section{Conclusions}

Following are the conclusions reached on the basis of this study.

Atrazine concentrations measured in the Platte River increased for two consecutive years. The atrazine profile measured in the river increased both in highest concentration measured and the total amount of atrazine transported in the river in 1990 and 1991 as compared with 1989. This can be attributed to the amount of rain received and the time in which the rains were received in the Platte Valley basin. In 1990, light rains, less than 1.0 inch, were received in midand late June and caused the available atrazine to be carried in the river. In 1991, heavy rains received in May and early June contributed large increases in the amount of atrazine transported in the river.
A lag time of 21 days was determined for the movement of atrazine, via induced recharge, in the south wellfield in the region of monitoring well 88-6. Figure 3 shows the delay between the concentration highs of atrazine in the river and its corresponding peaks in monitoring well 88-6. Three distinct peaks in both the river and monitoring well can be correlated with each other. An average travel time between these peaks of concentration was determined to be 21 days. This is significantly different from the reported 10-day delay in 1989 (Duncan et al. 1991). In 1991, a large band of atrazine was transported down the river at a much greater concentration than in 1989. This delay time can be used to calculate travel rates and estimate dispersivities in this region.

Colloidal particles play an insignificant role in the transport of atrazine in the river and from the river into the aquifer. No change in atrazine concentration was seen when controlled pore size filtration techniques were used to filter river and ground water samples. Therefore, atrazine was present in the river and the adjacent aquifer as the dissolved molecule.

Atrazine concentrations measured in precipitation correlate well with the time of application. The first detection and initial increase of atrazine in precipitation were in early spring during application to corn and sorghum plantings. After the application season, the concentration of atrazine measured in precipitation leveled off and then decreased to undetectable levels later in the year. It is probable that the atrazine concentration in rain water depends on the amount of precipitation received, the frequency of precipitation, and the timing of the precipitation in relation to application. Insufficient data were obtained to correlate the amount of rain and the frequency of the rains to levels of atrazine found in rain water. Levels of atrazine found in precipitation were below the EPA limit of $3 \mathrm{ppb}$ for drinking water.

A significant degradation of raw water quality is seen in the aquifer adjacent to the river. From the data in Table 4, it is evident that 11 of the 26 production wells contained significant levels of atrazine. This corresponds to about 40 percent of the production wells being recharged with contaminated water from the river within 40 days. After this time period, degradation and dispersion significantly reduced the effects of induced recharge, but elevated concentrations of atrazine were still measured in production wells about 1500 feet from the river.

\section{Acknowledgments}

We would like to express our appreciation and gratitude to the groups and individuals that made the project possible. The majority of the financial support was provided by the city of Lincoln, Nebraska. The Conservation and Survey Division, the Institute of Agriculture and Natural Resources, and the University of Nebraska- Lincoln provided drilling and equipment support. 


\section{References}

Black and Veatch. 1964. Report on Water Works Improvements for Lincoln, Nebraska. Kansas City, Missouri.

Brogden, R. E. 1972. A model of a Platte-Elkhorn Valley Aquifer. Unpublished master's thesis. Department of Civil Engineering, University of Nebraska-Lincoln.

Buser, H. R. 1990. Atrazine and other s-triazine herbicides in lakes and rain in Switzerland. Environmental Science and Technology, v. 24, no. 7, pp. 1049-1058.

Chu, T. M. 1988. Investigation of the Thermal Regime in a River-Aquifer System Near Ashland, Nebraska. Unpublished master's thesis, Department of Geology, University of Nebraska-Lincoln. 113 pp.

Cohen, S. Z., R. F. Carsel, S. M. Creeger, and C. G. Enfield. 1984. Potential Pesticide Contamination of Groundwater from Agricultural Uses; in "Treatment and Disposal of Pesticide Wastes" ACS Symposium Series. pp. 297-325.

Dao, T. H., T. L. Lavy, and R. C. Sorensen. 1979. Atrazine degradation and residue distribution in soil. Soil Sci. Soc. Am. J., v. 43, pp. 1129-1134.

Davis, S. N., G. M. Thompson, H. W. Bentley, and G. Stiles. 1980. Ground water tracers - A short review. Ground Water, v. 18, pp. 14-22.

Duncan D. G., D. T. Pederson, T. R. Shepherd, and J. D. Carr. 1991. Atrazine used as a tracer of induced recharge. Ground Water Monitoring Review, v. 9, no. 4, pp. 144-150.

Freeze, R. A. and J. A. Cherry. 1979. Groundwater. Prentice-Hall Inc., Englewood Cliffs, New Jersey, p. 384.

GMI. 1987. Ashland project reports, The comprehensive development plan. Groundwater Management Inc., Kansas City, Kansas.

Layne-Western Co. Inc. 1984. Lincoln Hydrology Study - Ashland Well Field Area, Platte River Valley, Nebraska. Kansas City, Kansas.

Marlette, R. R. 1952. Field Determinations of the Transmissibility and Storage Coefficients of the Platte Valley Aquifer Near Ashland, Nebraska. Unpublished master's thesis, Department of Civil Engineering, University of NebraskaLincoln, 88 pp.

Obrist, Jerry. 1983. Water Production Performance Study, Lincoln Water System, Lincoln, Nebraska. Unpublished report, city of Lincoln, Nebraska, City Engineers Files. 6 pp.

Shepherd, T. R., J. D. Carr, D. G. Duncan, and D. T. Pederson. 1992. C-18 extraction of atrazine from small water sample volumes. J. AOAC International, v. 75, pp. 581-583.

Shepherd, T. R. 1991. Monitoring of Sub-Part-Per-Billion Levels of Atrazine as a Determinate of Subsurface Water Motion Under Induced Recharge. Doctoral dissertation. Department of Chemistry, University of Nebraska-Lincoln.

Snow, D. D. and R. F. Spalding. 1988. Soluble Pesticide Levels in the Platte River Basin of Nebraska. Institute of Agriculture and Natural Resources, University of NebraskaLincoln. pp. 211-233.

Souders, V. L. 1967. Availability of water in eastern Saunders County, Nebraska. USGS Hydrologic Atlas 266.

USGS, Department of the Interior. 1991. Personal communication. Nebraska District, Lincoln, Nebraska.

\section{Biographical}

Darryl A. Blum earned his M.S. in analytical chemistry in 1992 at the University of Nebraska-Lincoln, and is a Ph.D. graduate student in the Department of Chemistry (227 Hamilton Hall, University of Nebraska-Lincoln, Lincoln, NE 68588).

James D. Carr earned his Ph.D. in analytical chemistry in 1966 at Purdue University, and is professor in the University of Nebraska-Lincoln Department of Chemistry (227 Hamilton Hall, University of Nebraska-Lincoln, Lincoln, NE 68588).

Ralph K. Davis earned his Ph.D. in hydrogeology in 1992 at the University of Nebraska-Lincoln, and is an assistant professor in the Department of Earth Sciences and Physics at the University of South Dakota (4I4 E. Clarke St., University of South Dakota, Vermillion, SD 57069).

Darryll T. Pederson earned his Ph.D. in 197I at the University of North Dakota, and is a professor in the University of Nebraska-Lincoln Department of Geology and a research hydrogeologist in the Conservation and Survey Division (304 Bessey Hall, University of Nebraska-Lincoln, Lincoln, NE 68588). 